\title{
NON-AGENDA
}

With the view of causing an increase to take place in the mass of national wealth, or with a view to increase of the means either of subsistence or enjoyment, without some special reason, the general rule is, that nothing ought to be done or attempted by government. The motto, or watchword of government, on these occasions, ought to be - Be quiet. . . Whatever measures, therefore, cannot be justified as exceptions to that rule, may be considered as non-agenda on the part of government.

\section{Do-It-Yourself Labour Market Reform: The Promise of Agency Contracting}

\author{
Ken Phillips
}

$\mathbf{M}$

any people have heard of 'Troubleshooters' and most associate the name vaguely with a noisy court victory over trade unions some years ago. Yet few know the details and implications of what actually occurred.

In 1991 the High Court ruled in favour of Troubleshooters and in so doing legitimised perhaps the most substantial assault ever launched against Australia's industrial-relations system. Nearly four years on, the commercial implications of the legal precedents set by the case have barely been realised. But recent developments suggest this is about to change.

Troubleshooters was the trading name of Odco Pty Ltd, a labour-hire agency that successfully took action in 1989 against the Building Workers Industrial Union and others in the Federal Court for breaches of common law and of Sections 45D and 45E of the Trade Practices Act. ${ }^{1}$ The litigation of the union attracted much attention at the time but at the expense of the real significance of the legal rulings.

The judgment of August 1989 by Mr Justice Woodward had the effect of making legal the use of contractual arrangements in the workplace through agencies, something never before achieved in Australia. The Full Court of the Federal Court upheld the decision on appeal; and the matter was finally settled on 7 June 1991, when the

'Odco Pty Ltd v Building Workers' Industrial Union of Australia and Others (1989), Federal Court of Australia, No. VG 151 of 1988, Woodward, J. 24 August, Melbourne (unreported).

2

(1991) 99 ALR 735 at 775. 
High Court rejected an application to seek leave to appeal. Odco Pty Ltd was the classic 'mouse that roared': everyone said that it could not be done.

As a result of the ruling, contracting of workers using systems that comply with the Odco judgment is legal and beyond the reach of industrial-relations courts and legislation. The Odco precedents have withstood subsequent attempts by the federal government to overturn the High Court ruling. After the Odco judgment the government established a high-level, legal task force charged with devising legislation to defeat the judgment. But the resultant amendment to the federal Industrial Relations Act did no more than ensure that contractors were not paid less than the award rate - something that was consistent with the Odco judgment.

Given the widespread criticism of Australia's award system, it is surprising that the non-award option made available by the Odco judgment has been so rarely taken up. But recently a privately developed system of contracting known as 'agency contracting' has emerged. Agency contracting, operating under the Odco precedents, is up and running in Australia and appears to have a bright future.

Agency contracting operates within the strict technicalities of the legal precedents. The basic principles are as follows. Three parties are involved: the contractor, the agency and the business. The agency enters a contract with the business to supply it with contract workers. The contract worker enters a contract with the agency to supply services. The business pays the agency, which in turn pays the contractors. The agency administers all tax, superannuation, workcover and other statutory obligations.

Workers seeking to be agency contractors undergo a two-hour interview and are extensively briefed on the commitment required to be a self-employed person. Accepted workers sign a contract to supply services through the agency, which clearly establishes their status as contractors. They sign a PPS tax form, enter superannuation arrangements through the agency and provide public liability insurance as selfemployed contractors.

The judgment by Justice Woodward established the legal bona fides for agency contracting. In relation to Troubleshooters, Justice Woodward said,

... there is no contract at all between the men working through Troubleshooters and the builders for whom they perform work. They are there because of separate contracts between the builders and Troubleshooters and between Troubleshooters and the workers. Since there is no contract at all between the builders and the men, there can be no relationship of employer and employee.

Underhill and Kelly (1993:419) describe the system as 'one of enhanced contract labour where no legal employment relationship exists. The system is based on a worker as an individual contractor, subject to direction at a worksite but choosing to be at that worksite'. 
Because they involve no employment relationship, agency contracts fall outside the jurisdiction of industrial-relations courts. Instead, the system is subject to common-law precedent. The legal precedents established by the Odco judgment were based on servicing the building industry but are now being applied to the entire Australian workforce.

Trade union hostility to contracts is based on the belief that workers are being exploited if they work without the 'protection' of the award system. But to comply with Odco, agency contracts must be voluntary and non-exploitative. Justice Woodward said,

I am satisfied from the evidence ... that workers who seek jobs through Troubleshooters do so because it suits them to work this way ... They are in no sense being exploited by Troubleshooters, nor do they represent a source of cheap labour for employers.

Another argument against contracts is that business wants them solely in order to lower costs. Underhill and Kelly (1993:407), for example, argue that 'The central economic difference between contract and award labour rests on costs'. But Justice Woodward said,

I am not satisfied that this argument is valid, because there may well be questions of convenience which affect employers' decisions on these matters without necessarily being reflected in lower costs.

The reality is that agency contracting delivers productivity. Trade unionists and defenders of the award system generally fail to comprehend the change in attitude that occurs when workers cease to be employees and become independent business persons. Businesses using agency contracting achieve productivity increases that more than offset any additional costs.

Effective union opposition to the system is minimal. The judgment firmly established the right of an agency to take action against vexatious union activity. Justice Woodward found that 'By taking industrial action ... the respondents have allegedly been guilty of ... the common law wrong of inducement to breach of contract'.

Agency contracting has not generally been promoted by business associations. Rather, a quiet revolution is occurring as the process spreads from one business to another around Australia. Perhaps surprisingly, many union officials who formerly opposed the system now work as contractors; some are clients and others are even operating agencies. They have discovered the secret of agency contracting: it provides mutual financial benefit to all parties involved.

\footnotetext{
${ }^{4}$ Id. 11.

5 Id. 45.

6

Id. 4 .
} 
Underhill and Kelly (1993:418) observed that "further attempts may be made to intraduce this model [Odco precedents] . . . now that the possibility of future success is legally assured'. With the development of the agency contracting, their forecast is being borne out, and do-it-yourself labour-market reform is under way in Australia.

\section{Reference}

Underhill, E. \& D. Kelly (1993), 'Eliminating Tradicional Employment: Troubleshooters Available in the Building and Meat Industries', Journal of Industrial Relations 35(3): 398-423.

Ken Phillips is a Melbourne-based employment and workplace reform consultant.

\section{Overseas Assembly Provisions: A Hidden Producer Subsidy}

\section{Darren Kennedy}

$\mathrm{O}$ verseas Assembly Provisions (OAPs) are a recent policy initiative in the textile, clothing and footwear (TCF) industries. OAPs permit approved TCF manufacturers to assemble garments overseas using Australian fabrics and to import the final products back into the country at a concessional rate of duty. The introduction of OAPs acknowledges that Australia has a high labour cost disadvantage relative to other TCF manufacturers, and attempts to improve the competitiveness of its TCF sector by shifting production away from labour-intensive activities. But although they allow Australian firms to benefit from lower offshore wages, OAPs tackle the existing problems created by import protection only indirectly, and do not necessarily reduce the welfare cost of the current distortions.

\section{OAPs and Protection}

OAPs are meant to discourage local labour-intensive production activity and to allow Australian firms to benefit from low foreign wages. The provisions aim to promote specialisation in other areas of the industry, such as textile manufacture and clothing design. The Textile, Clothing and Footwear Development Authority (TCFDA), which monitors industry progress under the TCF Plan, believes that Australian firms have the potential to specialise, and to become internationally competitive, in the higher value-added activities sucl as textile and clothing design, textile production, and marketing (TCFDA, 1993:12).

OAPs originated in the context of the protectionist policy that spanned the post-war years to the early 1980s. Import protection was allocated on a made-to- 